\title{
Therapeutic role of MSCs-derived exosomes for Alzheimer's disease
}

\author{
Sanaa M.R. Wahba ${ }^{1}$, Aliaa R.H. Mostafa ${ }^{2}$ and Sara M. Kamal ${ }^{1, *}$. \\ ${ }^{1}$ Zoology department, Faculty of Women for Arts, Science and Education, Ain Shams University. \\ ${ }^{2}$ Basic Science department, Faculty of Oral and Dental Medicine, Future University.
}

\begin{abstract}
The discovery of mesenchymal stem cell-derived exosomes (MSCs-derived exosomes) has shed a new light in the development of disease-modifying treatments for Alzheimer (AD). The present study is an attempt to investigate the influence of these extracellular vesicles (exosomes) in Alz therapy. A total of 38 adult female albino Wistar rats were randomly assigned to the following groups: Control group (C) of 8 rats given saline; Alzheimer's group (Alz) of 15 ovariectomized animals inoculated orally with $\mathrm{AlCl}_{3}(17 \mathrm{mg} / \mathrm{Kg}$ b.wt/day) for 2 months after 6 weeks of surgical operation and 15 Alzheimer's disease-induced rats treated (i.v) with $\left(10^{7}\right.$ MSCs-derived exosomes/rat/week). After 2 and 4 weeks animals were sacrificed by ether inhalation anesthesia where brains were removed and processed for histological investigation by $\mathrm{Hx} \& \mathrm{E}$ and biochemical analysis for measuring $\beta$-Amyloid 1-42 and Brain derived neurotrophic factor (BDNF) levels.
\end{abstract}

Key words: Alzheimer (Alz), Mesenchymal stem cells (MSCs), Exosomes.

\subsection{Introduction}

Alzheimer's disease (AD), which is an irreversible, progressive, neurodegenerative \& terminal disease, is the most common form of dementia [1]. It is characterized by progressive degeneration of the hippocampal and cortical neurons that leads to impairment of memory and declining of cognitive functions [2].

$\mathrm{AD}$ is pathologically characterized by two major protein abnormalities: neurofibrillary tangles (NFT) and amyloid plaques (A $\beta)[3]$.

It was however concluded that the oral administration of aluminium chloride $\left(\mathrm{AlCl}_{3}\right)$ could induce brain damage in rats and $\mathrm{so}, \mathrm{AlCl}_{3}$ induction could be used to form $\mathrm{AD}$ model in experimental animals [1].

*Corresponding author: Sara Mostafa Kamal; Zoology department; Faculty of Women for Arts, Science and Education - Ain Shams University.

E-mail: sara.m.kamal88@gmail.com. 
Many investigations studied the correlation between aluminium accumulation and oxidative damage in the brain. It was found that $\mathrm{AlCl}_{3}$ is able to cross the blood brain barrier inducing elevation of lipid peroxidation due to participation of free-radical-induced oxidative cell injury and so enhancing oxidative stress in the brain, thereby disturbing the antioxidant defense. Increased oxidative stress could be one of the mediating factors in the pathogenesis of $\mathrm{AlCl}_{3}$ toxicity in the brain [4] as well as in the pathogenesis of $\mathrm{AD}[5]$.

Estrogen deficiency was reported to accelerate $\beta$-amyloid $(A \beta)$ plaque formation in an overiectomized $\mathrm{AD}$ rat model [6].

BDNF is a member of the neurotrophic factor family which is synthesized in basal forebrain and plays a key role in central nervous system. It can facilitate long-term memory potentiation and contributes a protective effect against the neurotoxicity of $A B$ peptide and repairs the damage induced by $\mathrm{A} \beta$ peptide [7].

Previous studies showed that a BDNF deficiency, resulting from a series of different factors, could associate with neuropsychiatric and neurodegenerative disorders and play an important role in $\mathrm{AD}$ progression [8].

There is no cure, prevention or treatment to slow the progression of Alzheimer's disease. Therefore, the discovery of stem cells has cast a new hope for the development of diseasemodifying treatments for $\mathrm{AD}[9]$.

Regarding the potential role of bone marrow-mesenchymal stem cells (BM-MSCs) in the treatment of $\mathrm{AD}$, it was found that they can promote the reduction of $\mathrm{A} \beta$ through the microglial activation and thus diminishes $A \beta$ deposits in the brain and they can also inhibit apoptotic cell death and oxidative stress resulting in improving cognitive deficits in the hippocampus [10].

It was found that direct tissue injection of stem cell for local stem cell delivery increases risks and side effects such as bleeding and tissue injury. Therefore, therapeutic effects are thought to arise from the release of extracellular factors (membrane-bound and soluble); among them, extracellular vesicles like exosomes which have gained much attention [11].

Exosomes are microvesicles of 30-100 nm in diameter and small lipid vesicles secreted by all cell types [12]. These nano-sized vesicles have ignited the light of hope in treating intractable neurodegenerative diseases such as Alzheimer's disease (AD). They are very 
stable; they can pass the blood-brain barrier (BBB) and therefore reveal bright perspectives towards diagnosis and therapeutic treatments [13].

\subsection{Material and Methods}

Thirty eight female adult albino Wistar rats from the Animal breeding colony of the Medical Research Centre Ain Shams University were employed in the present study. Their weights ranged between 110-170 gm representing an age group of 6 months. Animals were allowed a one week pre-experimentation period to adapt to laboratory conditions. They received food and water ad libitum with fresh supplies presented daily.

\section{Drugs:}

Aluminium chloride $\left(\mathrm{AlCl}_{3}\right)$ was purchased from Fluka Chemicals (Ronkonkama, NY) and was administered orally at doses of $17 \mathrm{mg} / \mathrm{kg}$ b.wt. daily for two months after 6 weeks of surgical operation [6].

Animals were divided according to the following design:-

a) Gonad intact rats (8) serving as normal control group (C).

b)Ovariectomized rats (30) inoculated orally with $\mathrm{AlCl}_{3}(17 \mathrm{mg} / \mathrm{kg}$ b.wt) daily for 2 months after 6 weeks of surgical operation for induction of Alz.

c)Then, 15 rats from the thirty Alzheimer's disease-induced rats were treated (i.v) with $\left(10^{7}\right.$ MSCs-derived exosomes/rat/week) for 2 and 4 weeks.

After 2 and 4 weeks rats were anaesthetized under ether inhalation and the brain was collected from all groups.

Half of each brain was washed in saline $(0.9 \% \mathrm{NaCl})$ and placed accordingly in $10 \%$ neutral buffered formalin for fixation and processed for histological investigation by Haematoxylin and Eosin for general histological examination [14]. The other half was frozen at $-80^{\circ} \mathrm{C}$ for biochemical analysis for the determination of Beta Amyloid 1-42 \{LifeSpan BioSciences, Inc. Rat Beta Amyloid 1-42 ELISA Kit (Sandwich ELISA). Catalog No. LSF23254 and BDNF \{Rat BDNF PicoKine ${ }^{\text {TM }}$ ELISA Kit. Catalog No. EK0308\} [15].

\section{Isolation and Culture of BM-MSCs:}

Under general anaesthesia, decontaminated technique and by using Rosenthal biopsy needle, bone marrow was collected from the iliac crest (stylet and needle, 15G, 1.8"). Bone marrow samples $(20 \mathrm{ml} / \mathrm{sample})$ were transferred to the lab then processed within 4 hours from the aspiration procedure [16]. 
Thirty five $\mathrm{ml}$ of the diluted sample was carefully layered above fifteen ml Ficoll-Paque (Gibco-Invitrogen, Grand Island, NY), centrifuged for thirty five minutes at 400xg rpm and the upper layer was removed leaving undisturbed mononuclear cell (MNC) layer at the interphase. This MNC layer was aspirated, washed twice in (phosphate-buffered saline) PBS containing $2 \mathrm{mM}$ EDTA and centrifuged for 10 minutes at $200 \mathrm{xg} \mathrm{rpm}$ at $10^{\circ} \mathrm{C}$. The cell pellet was re-suspended in a concluded volume of $300 \mu \mathrm{l}$ of buffer. Isolated MSCs were cultured on twenty five ml culture flasks in minimal essential medium (MEM) supplemented with $15 \%$ fetal bovine serum (FBS) and incubated for 2 hours at $37^{\circ} \mathrm{C}$ and $5 \% \mathrm{CO} 2$. Adherent MSCs were cultured in MEM supplemented with 30\% FBS, $0.5 \%$ penicillin, streptomycin and at $37^{\circ} \mathrm{C}$ in $5 \% \mathrm{CO} 2$ in air [17].

\section{Isolation and Culture of exosomes (Exo):}

1. MSC-derived exosomes were obtained from the supernatant of MSCs representing conditioned media. The conditioning media was transferred in a suitable centrifugation tube and centrifuged for $35 \mathrm{~min}$ at $3,000 \mathrm{x} \mathrm{g}, 4{ }^{\circ} \mathrm{C}$.

2. Supernatant was decanted; tubes were kept turned upside-down and put on a paper towel. Then left for 3 - 5 min until all remaining supernatant has been soaked into the towel and thereby removed from the sample.

3. The pellet was re-suspended in $1,000 \mu \mathrm{L}$ PBS, transferred to a $1.5 \mathrm{~mL}$ tube and centrifuged for $35 \mathrm{~min}$ at $10,000 \mathrm{x} \mathrm{g}, 4^{\circ} \mathrm{C}$ in a tabletop centrifuge.

4. Supernatant was aspirated.

5. The supernatant was subjected to an ultracentrifugation tube and centrifuged for $1 \mathrm{~h}$ at $100,000 \mathrm{x} \mathrm{g}, 4{ }^{\circ} \mathrm{C}$. The supernatant was decanted as described in step 2.3, Exo pellet was re-suspended in $1,000 \mu \mathrm{L}$ PBS and transferred into small $(1.5 \mathrm{~mL})$ ultracentrifugation tubes.

6. Ultracentrifugation was done for $1 \mathrm{~h}$ at $100,000 \mathrm{xg}, 4{ }^{\circ} \mathrm{C}$, supernatant was aspirated and Exo pellet was re-suspended in $50-75 \mu \mathrm{L}$ PBS.

7. The Exo protein concentration was determined with a protein assay (e.g., Bradford or Lowry method) in order to assess Exo yields or dose Exo for subsequent experiments.

\section{Transmission electron microscope (TEM) characterization for exosomes:-}

Exosomes were fixed with $2.5 \%$ glutaraldehyde for 2 hours, after being washed; exosomes were ultra-centrifuged and suspended in $100 \mu \mathrm{L}$ human serum albumin (HSA). A total of twenty $\mu \mathrm{L}$ of exosomes was loaded onto a formvar/carbon-coated grid, negatively stained with 
three $\%$ aqueous phosphor-tungstic acid for one minute and observed by TEM (HITACHI, H7650, Japan), which showed their spheroid morphology and confirmed their size [18].

Flow cytometric characterization of exosomes: (FACS analysis) [19].

1. Exosomes were harvested with tryps in (ethylenediaminetetraacetic acid) EDTA in (dulbecco's phosphate-buffered saline) DPBS then centrifuged at $200 \mathrm{~g}$ for $10 \mathrm{~min}$ at $5^{\circ} \mathrm{C}$ to collect exosomes.

2. The cells were counted with hemocytometer.

3. 100,000 exosomes in DPBS were stained for $20 \mathrm{~min}$ at room temperature with $10 \mu \mathrm{l}$ of antibody (exsosomal markers: CD63 and CD81).

4. $2 \mathrm{ml}$ of PBS were added to the exosomes then tubes were centrifuged at $200 \mathrm{~g}$ for $5 \mathrm{~min}$ at room temperature.

5. The supernatant was discarded and the labeled exosomes were finally resuspended in $0.5 \mathrm{ml}$ flow buffer (5\% FBS+95\%PBS).

6. The cells were analyzed on a flow cytometer Coulter Elite XL Calibur collecting 10,000 events.

\section{Statistical analysis}

In the present study, all results were expressed as mean \pm S.E. of the mean. Statistical Package for the Social Sciences (SPSS) program, version 10.0 was used to compare significance between each two groups. Difference was considered significant when $\mathrm{P} \leq 0.05$.

\subsection{Results}

\section{a.Characterization of exosomes:}

Cultured third passage of BM-MSCs give rise to exosomes which were analyzed by electron microscopy that represented micrographs for spheroids exosomes with diameter less than 100nm (Fig. 1a). FACS analysis of exosomes showed that they acquired surface markers such as CD63 (99.6\%) and CD81 (99.9\%) (Fig. 1b). 


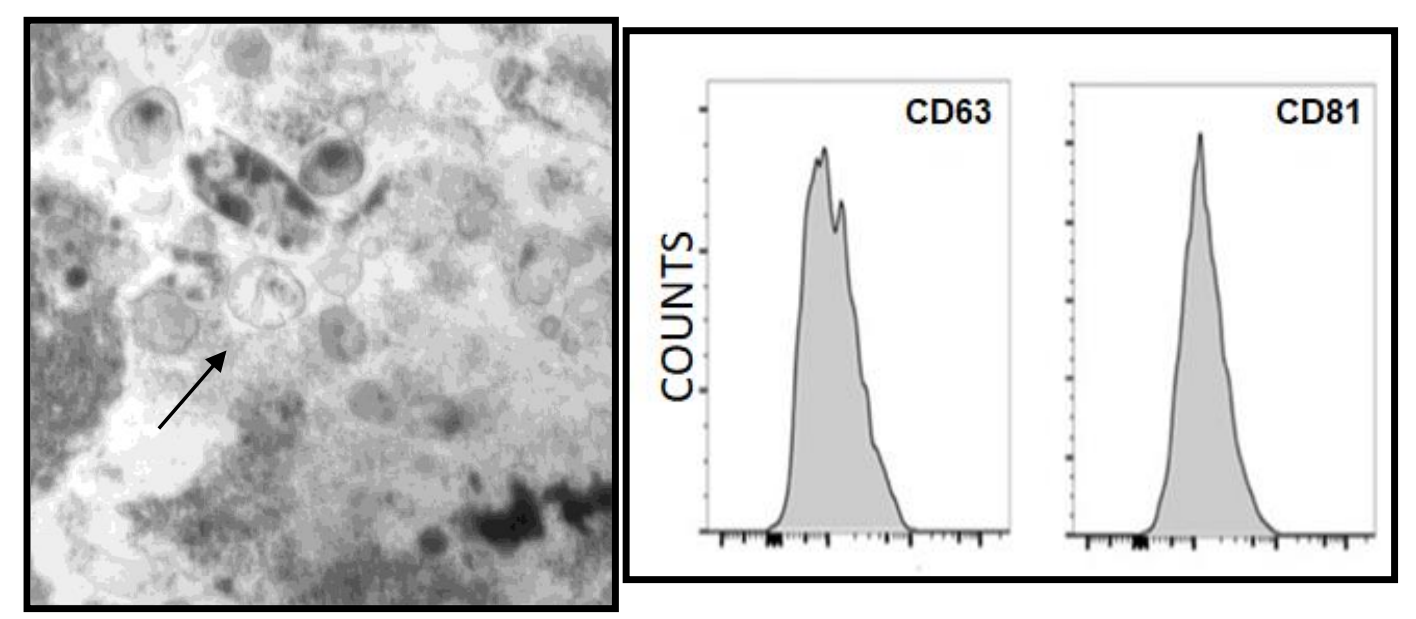

(a)

(b)

Fig. (1): Characterization of exosomes, a) Exosomes were analysed by electron microscopy that represented micrographs for spheroids exosomes (arrow). b) FACS analysis of exosomes showed that they acquired surface markers such as CD63 (99.6\%) and CD81 (99.9\%).

b. Histological investigations: Microscopic examination of brain sections of normal control rats (Fig. 2a) showed normal morphological structure of the hippocampus \& neurons; while brain sections of AD-induced group demonstrated few degenerative areas in the cerebral cortex and in the hippocampus with well-observed plaques, congestion with perivascular edema, loss of pyramidal cells and separation of cortical tissue (Fig. 2b\&c). Following MSCs-derived exosomes therapy for 2 weeks rat brain sections presented degeneration in some of the hippocampal neurons (Fig.2d). Rat brain sections designated near to normal patterns following 4 weeks of MSCs-derived exosomes treatment (Fig 2e \& 2f). 


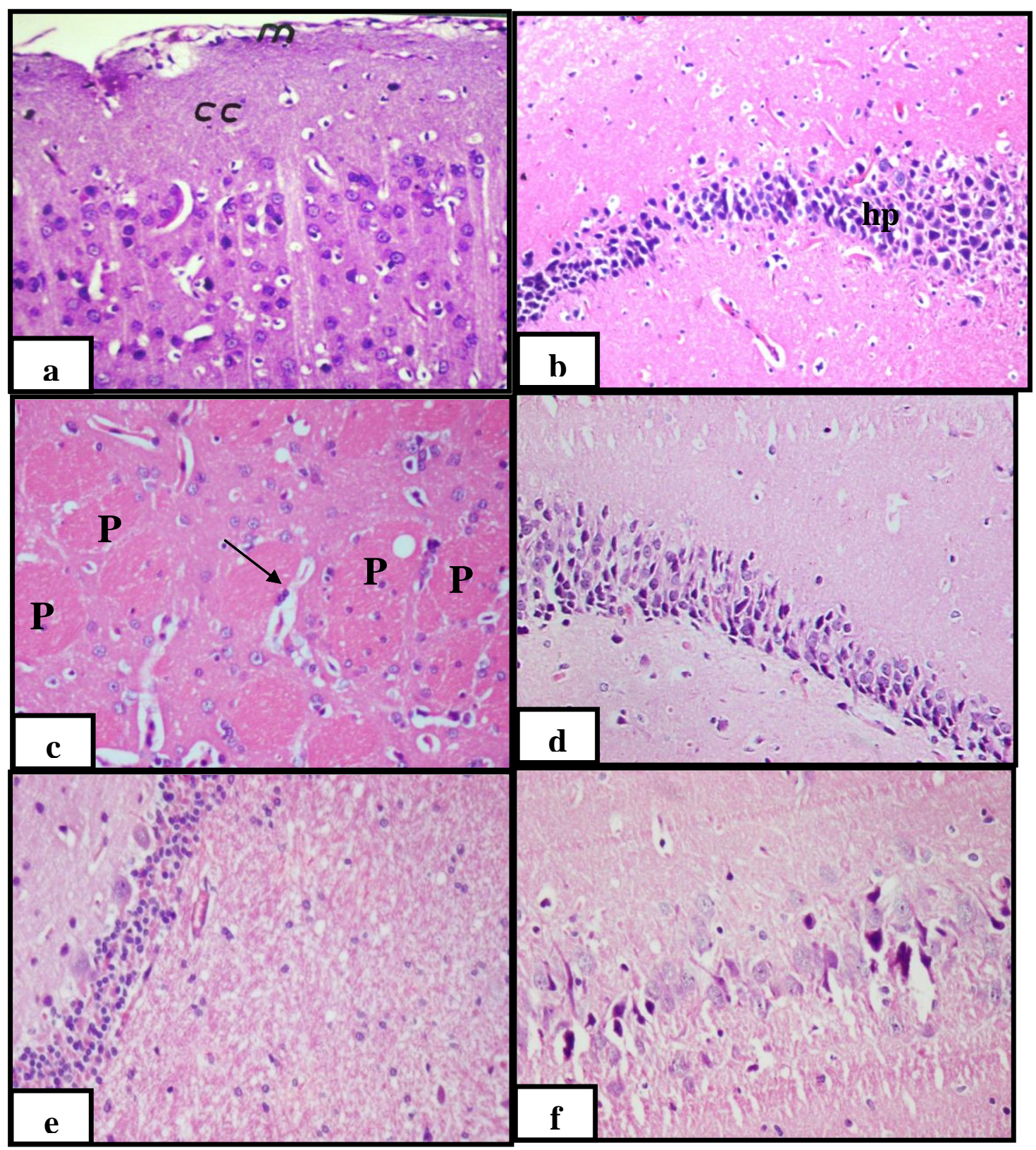

Fig 2: Photomicrograph of brain sections from control and experimental groups showing normal brain architecture (Fig.2a), degenerated neurons in the hippocampus (hp), amyloid plaques (p) of different sizes, congestion with perivascular edema (arrow), loss of pyramidal cells and separation of cortical tissue were manifested following Alz induction (Fig 2b \& 2c). Following MSCs-derived exosomes therapy for 2 weeks rat brain sections presented degeneration in some of the hippocampal neurons (Fig.2d). Rat brain sections designated near to normal patterns following 4 weeks of MSCs-derived exosomes treatment (Fig 2e \& 2f) (H\&E x200). 
c. Biochemical investigations: In the present investigation, a significant increase in the content of $\beta$-Amyloid 1-42 and a significant depletion of BDNF were shown in Alz-induced rats group as compared with the control. By treatment with MSCs-derived exosomes, limited improvement in each of $\beta$-Amyloid 1-42 and BDNF was recorded after 2 weeks as compared to Alz group. On the other hand, near to normal levels of $\beta$-Amyloid 1-42 and BDNF were recorded after 4 weeks comparing to $\mathrm{Alz}$ group. These results validate fore mentioned histopathological alterations (Table 1).

Table (1): Therapeutic role of MSCs-derived exosomes in brain tissue of control and experimental groups

\begin{tabular}{|c|l|l|l|l|}
\hline Parameters & & \multicolumn{1}{|c|}{ C } & Alz & Alz+MSCs-derived \\
\hline $\begin{array}{c}\text { B-Amyloid 1-42 } \\
\text { (pg/mg tissue) }\end{array}$ & 2 weeks & $67.70 \pm 5.66$ & $275.66 \pm 22.71^{\mathrm{a}}$ & $173.93 \pm 39.85^{\mathrm{a}, \mathrm{b}}$ \\
\hline BDNF & 2 weeks & $65.55 \pm 8.70$ & $307.50 \pm 23.73^{\mathrm{a}}$ & $107.45 \pm 11.31^{\mathrm{a}, \mathrm{b}}$ \\
\hline (pg/mg tissue) & 4 weeks & $158.20 \pm 6.36$ & $54.16 \pm 3.90^{\mathrm{a}}$ & $135.25 \pm 4.64^{\mathrm{b}}$ \\
\hline
\end{tabular}

a: Significant as compared with control group (using two-sample t-test assuming unequal variances with $\alpha=0.05)$.

b: Significant as compared with Alz group (using two-sample t-test assuming unequal variances with $\alpha=0.05)$.

\subsection{Discussion}

Alzheimer's disease is a neurological disorder in which the death of brain cells causes memory loss and cognitive decline. It is a neurodegenerative type of dementia; the disease starts mild and gets progressively worse [20].

In the present investigation, following Alz induction, several histological alterations were manifested as amyloid plaque formation of different sizes; congestion with perivascular edema and degenerated neurons with diffused gliosis.

Also shrunken neurons; dark stained nuclei; neurofibrillary degeneration and neuronal loss were observed in hippocampus of rats [6]. 
Al can induce oxidative damage through multiple mechanisms as it can bind to negatively charged brain phospholipids, which contain polyunsaturated fatty acids; stabilizes iron in its reduced ferrous $\left(\mathrm{Fe}^{2+}\right)$ state and promotes iron-initiated lipid peroxidation in the redox reaction producing $\mathrm{Fe}^{3+}$ and reactive oxygen species (ROS). They cause cellular damage, by oxidizing amino acid residues on proteins, forming protein carbonyls which are a standard marker for oxidative stress in many diseases as AD [21].

Despite the means of knowledge that has been generated in the past decades, a reliable cure for neurodegenerative disorders remains vague. In this study, the effect of MSCs-derived exosomes as a new treatment for AD chemically induced in rats was investigated.

Stem cell -based therapy is a promising approach to handling neurodegenerative diseases. It has been postulated that stem cell therapies may replace lost cells by differentiating into functional neural tissue; modulate the immune system to prevent further neurodegeneration and provide a source of trophic support for the diseased nervous system [22].

Among various stem cells, those derived from bone marrow contribute to cell repair in various tissue types including brain. MSCs, a group of multipotent stem cells and immunesuppressive cells, are the most widely used and offer great promise to treat AD [23]. Moreover, MSCs significantly enhance autolysosome formation and clearance of $A ß$ in $A D$ models [24].

Consequently, one of the key limits for a non-invasive systemic therapy of CNS disorders is the fact that several substances are not able to cross the BBB. Regarding exosomes, a new potential therapy for CNS disorders was potentiated [11].

In the concurrent study, it was noticed that $\mathrm{AD}$-induced rats treated with MSCs-derived exosomes for 2 weeks showed limited attenuation of amyloid plaques; pyknotic changes and degeneration in some cortical neurons. After 4 weeks of treatment, near to normal cerebral patterns; normal neuronal cells; complete disappearance of amyloid plaques were manifested.

In the present investigation, a significant elevation in the contents of B-Amyloid 1-42, while a significant depletion in tissue $\mathrm{BDNF}$ content in $\mathrm{AD}$-induced rats group were realized 
compared with the control group. As AD-induced rats were treated with MSC-derived exosomes for 2 and 4 weeks near to normal improvement in each of B-Amyloid 1-42 and BDNF was recorded.

Exosomes which are extracellular nano-vesicles secreted by stem cells were able to cross the $\mathrm{BBB}$ when injected systemically; achieve the brain parenchyma; target the brain cells and modify their function by delivering proteins, lipids and nucleic acids [12]. In AD research, it was found that exosomes could act on $A \beta$ to reduce injury in the nervous system [25]. Improving $A \beta$ clearance by exosome administration provides a novel therapeutic intervention for AD. They can also stimulate the production of neurotrophins such as vascular endothelial growth factor (VEGF), nerve growth factor (NGF), brain-derived neurotrophic factor (BDNF) and neurotrophin-3 which increase neuritic development, promote neurorestoration and neurological recovery [26].

\subsection{Conclusion}

MSCs-derived exosomes may overcome the therapeutic drawback of drugs used in AD treatment and so, induce successful therapeutic role to such progressive, neurodegenerative and terminal disease.

\subsection{References}

[1] M.M. Said, G.A. Elmenoufy, "The possible neurotherapeutic effects of Mesenchymal stem cells on $\mathrm{AlCl}_{3}$-induced Alzheimer's disease in adult albino rats", OSR-JPBS (2015) 10(5):33-40.

[2] Y. Tang, M.W. Lutz, Y.Xing, "A systems-based model of Alzheimer's disease", Alzheimers Dement. (2019) 15(1):168-171.

[3] F. Kametani, M. Hasegawa, "Reconsideration of Amyloid Hypothesis and Tau Hypothesis in Alzheimer's disease", Front Neurosci. (2018) 12: 12-25.

[4] N.R. Naidu, S. Bhat, U. Dsouza, "Effect of long term administration of aluminum chloride on oxidative stress and acetylcholinesterase activity in rat brains", IJPBS (2013) 3(1):616-622.

[5] S.M.R. Wahba, A.S. Darwish, S.M. Kamal, "Ceria-containing uncoated and coated hydroxyapatite-based galantamine nanocomposites for formidable treatment of Alzheimer's disease in ovariectomized albino-rat model", Mater Sci Eng C Mater Biol Appl. (2016) 65:151-163.

[6] S.M. Kamal, 2015 M.Sc. Thesis "Galantamine bioactivity improvement in rat brain using various novel nano-drug delivery systems as therapy for Alzheimer's disease", (Women's college for Arts, Sc. and Edu., Ain Shams University). 
[7] G. Li, R. Bi, D. Zhang, M. Xu, R. Luo, D. Wang, Y. Fang, T. Li, C. Zhang, Y. Yao, "Female-specific effect of the BDNF gene on Alzheimer's disease", Neuro Biol Aging. (2017) 53(192): 11-19.

[8] M.L. Giuffrida, A. Copani, E. Rizzarelli, "A promising connection between BDNF and Alzheimer's disease", Aging (Albany NY), (2018) 10(8): 1791-1792.

[9] M. Alipour, S.M. Nabavi, L. Arab, M. Vosough, H. Pakdaman, E. Ehsani, K. Shahpasand, "Stem cell therapy in Alzheimer's disease: possible benefits and limiting drawbacks", Mol. Biol. Rep.(2019) 46(1):1425-1446.

[10] J.K. Lee, H.K. Jin, J.S. Bae, "Bone marrow-derived mesenchymal stem cells attenuate amyloid $\beta$-induced memory impairment and apoptosis by inhibiting neuronal cell death", Curr. Alzheimer Res. (2010) 7(6):540-548.

[11] A. Luarte, L.F. Bátiz, U. Wyneken, C. Lafourcade, "Potential therapies by stem cellderived exosomes in CNS diseases: focusing on the neurogenic niche", Stem Cells Int., (2016) ID: 5736059.

[12] Z. Cai, M. Xiao, S.H. Quazi, Z. Ke, "Exosomes: a novel therapeutic target for Alzheimer's disease?", Neural Regen. Res. (2018) 13(5):930-935.

[13] L.C. Liew, T. Katsuda, L. Gailhouste, H. Nakagama, T. Ochiya, "Mesenchymal stem cell-derived extracellular vesicles: a glimmer of hope in treating Alzheimer's disease", Int. Immunol. (2017) 29(1):11-19.

[14] H. Kothmaier, D. Rohrer, E. Stacher, F. Quehenberger, K.F. Becker, H.H. Popper, "Comparison of formalin-free tissue fixatives: a proteomic study testing their application for routine pathology and research", Arch. Pathol. Lab Med. (2011) 135(6): 744-752.

[15] J. Schulze, O. Kaiser, G. Paasche, H. Lamm, A. Pich, A. Hoffmann, T. Lenarz, A. Warnecke, " Effect of hyperbaric oxygen on BDNF-release and neuroprotection: Investigations with human mesenchymal stem cells and genetically modified NIH3T3 fibroblasts as putative cell therapeutics", PLoS One. (2017) 12(5): e0178182.

[16] A.Mokbel, O. ElTookhy, A.A.Shamaa, D.Sabry, L.Rashed, A.Mostafa, "Homing and efficacy of intra-articular injection of autologous mesenchymal stem cells in experimental chondral defects in dogs" Clin Exp Rheumatol. (2011) 29:275-284.

[17] F. Torad, M. Amer, A. Shamaa, O. El-Tookhy, D. Sabry, L. Rashed, M. Abd E1 Hamid, S. Mahfouz, D. Gharib, “Long Term Evaluation of Human Umbilical Cord Blood Mesenchymal Stem Cells in the Management of Total Coronary Occlusion (Experimental Study in Dogs)" Asian J. Anim. Sci. (2015) 9 (6): 266-279.

[18] E. GATTI, N.D. VIRGILIO, M. S. MAGLI, "PREDIERI, INTEGRATING SENSORY ANALYSIS AND HEDONIC EVALUATION FOR APPLE QUALITY ASSESSMENT" J. Food Qual. (2011) 34:126-132.

[19] A. Othman, R. Mubarak, M. Sameer, D. Sabry, "Fibroblast growth factor-6 enhances CDK2 and MAKT expression in microvesicles derived from human stem cells extracted from exfoliated deciduous teeth" F1000. (2019) 7:610-622.

[20] MNT,(2014):http://www.medicalnewstoday.com/images/articles/159442-alzheimers-brainneurons.jpg. 
[21] B.A. Berihu, M. Afwerk, Y.G. Debeb, A. Gebreslassie, "Review on Histological and Functional Effect of Aluminium Chloride on Cerebral Cortex of the Brain", IJPSR (2015) 6(8): 1105-1116.

[22] A.M. Salem, H.H. Ahmed, H.M. Atta, M.A. Ghazy, H.A. Aglan, "Potential of bone marrow mesenchymal stem cells in management of Alzheimer's disease in female rats", Cell Biol Int. (2014) 38(12):1367-1383.

[23] A. Caplan, D. Correa, "The MSC: an injury drugstore", Cell Stem Cell. (2011) 8;9(1):11-15.

[24] J.Y. Shin, H.J. Park, H.N. Kim, S.H. Oh, J.S. Bae, H.J. Ha, P.H. Lee, "Mesenchymal stem cells enhance autophagy and increase $\beta$-amyloid clearance in Alzheimer disease models", Autophagy (2014) 10(1):32-44.

[25] L. Jiang, H. Dong, H. Cao, X. Ji, S. Luan, J. Liu, "Exosomes in Pathogenesis, Diagnosis, and Treatment of Alzheimer's Disease", Med Sci Monit. (2019) 25: 3329-3335.

[26] M.T. Harting, A.K. Srivastava, S. Zhaorigetu, H. Bair, K.S. Prabhakara, N.E. Toledano Furman, J.V. Vykoukal, K.A. Ruppert, J.R. Cox CS, S.D. Olson, "InflammationStimulated Mesenchymal Stromal Cell-Derived Extracellular Vesicles Attenuate Inflammation", J. Stem Cells (2018) 36(1):79-90. 


\section{الدور العلاجى للإكسوزومز المستنبطة من خلايا نخاع العظم لمرض الألزهايمر}

1 سناء محمد رفعت و هبةـ 2علياء رجائى حسن مصطفى ـاسارة مصطفى كمال

1: قنسم علم الحيوانـ كلية البنات للاداب و العلوم و التربية - جامعة عين شمس

2: قسم العلوم المساعدة- كلية طب الفم والأسنان - جامعة المستقبل

إن إكتثاف الإكسوزومز المستتبطة من خلايا نخاع العظم قد ألقى ضوءا جديدا فى تطوير علاجات معدلة لمرض هار

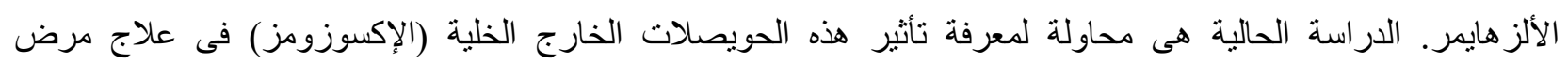
الألز هايمر.

وقد أجريت الدراسة على 38 من اناث الجرذان البيضاء البالغة. وتم تقسيم الجرذان عشوائيا الى 3 مجموعات: المجموعة الظابطة المكونة من 8 فئران وتم إعطائها محلول ملحى والمجموعة التجريبية المكونة من 15 فأر والتى نم از الة المبيضين منهما

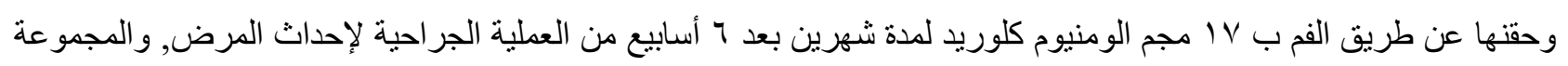
المريضة المكونة من 15 فئران والتى عولجت عن طريق حقن بالوريد ب (107/كجم/الإسبوع) إكسوزومز المسنتبطة من خلايا نخاع العظم.

ثم بعد أسبو عين من الحقن تم اختيار نصف عدد الجرذان عشو ائيا من كل مجموعة وبالمثل استخدمت بقية الجرذان بعد مرور أربع أسابيع. وأجريت عمليات التشريح واز الة الرؤوس لأخذ المخ لإجر اء دراسة نسيجية بإستخدام صبغة الهيماتو كسلين والإيوسين ودر اسة بيو كيميائية تحليلية لقياس معدلات البيتاأميلويد (1-42) و عامل التغذية العصبية المشتق من الدماغ. 